\title{
Legislating Morality: The Effects Of Tax Law Complexity On Taxpayers' Attitudes
}

\author{
David A. Nugent, Robert Morris University, USA
}

\begin{abstract}
This paper addresses the effects of tax law complexity on the behavior of taxpayers. A particular focus is the effect of tax law complexity on taxpayers' perceptions of the morality of taking deductions that might be disallowed. The topic of taxpayer morality is addressed in terms of the broader concept of deterrence theory, which suggests that deterrence factors include formal punishment, informal social punishment and the guilt that would be felt if a behavior were perceived to be immoral. Tax law complexity may give rise to the perception that taking a questionable deduction would be socially acceptable tax avoidance rather than socially unacceptable tax evasion, and that taking a questionable deduction is morally acceptable. It is hypothesized that greater tax law complexity is associated with less perception that taking questionable deductions is immoral, and that less perception that taking questionable deductions is immoral is associated with greater inclination to take questionable deductions. Accordingly, it is hypothesized that greater tax law complexity is associated with greater inclination to take questionable deductions. The study entailed an experimental survey in which subjects evaluated hypothetical scenarios in which the opportunity existed to save taxes by taking a deduction that might be disallowed. ANOVA and Regression results were consistent with the hypotheses.
\end{abstract}

Keywords: Tax Law Complexity; Deterrence Theory; Deterrence Factors; Tax Evasion; Tax Avoidance

\section{INTRODUCTION}<smiles>[CH]1CCCCC1</smiles>

$t$ is sometimes said that you cannot legislate morality. The results of this study suggest that maybe you can. This paper addresses the effects of tax law complexity on the behavior of individual taxpayers. A particular focus is the possibility that tax law complexity may affect taxpayers' perceptions of the morality of taking deductions that might be disallowed, and that those perceptions of morality may affect taxpayers' inclinations to take deductions. This paper suggests that if a tax law is clear and precise, taxpayers may view the taking of a questionable deduction to be immoral. In turn, it is suggested that taxpayers who consider the taking of a particular deduction to be immoral will be inclined to not take the deduction. Conversely, if a tax law is vague and complex, taxpayers may be less prone to view the taking of a questionable deduction to be immoral. Such taxpayers may be inclined to take the deduction. If an observer were to adopt the position that taking a questionable deduction is immoral, then it could be argued that the passing of clear, precise tax laws could be viewed as the legislation of morality, while the passing of complex tax laws could be viewed as the legislation of immorality.

The study entailed an experiment in which subjects evaluated hypothetical scenarios. Through an experimental questionnaire, subjects were asked to imagine that in the preparation of their personal tax returns, they faced the opportunity to save taxes by taking a deduction that might be disallowed. Manipulated variables were probability of disallowance and degree of tax law complexity related to the potential deduction. Variables measured through a questionnaire included subjects' attitudes toward the morality of taking deductions and expectations of social consequences, as well as subjects' inclinations to take deductions. 


\section{THEORY AND HYPOTHESES}

\section{The Influence of Complexity}

Previous research on the relationship between tax law complexity and taxpayer compliance suggests that effects of tax law complexity may include influencing taxpayers' risk attitudes and perceptions of costs, as well as taxpayers' perceptions of equity.

Regarding risk attitudes, it is suggested that tax law complexity may either increase or decrease taxpayer compliance depending on perceptions and conditions. Some studies (Alm, 1988; Hite and McGill, 1992; Westat, 1980) suggest tax law complexity may increase compliance by inducing caution. If taxpayers associate uncertainty with risk, and if tax law complexity creates the perception of uncertainty regarding proper tax treatment, cautious taxpayers may be more likely to be compliant. Boortz and Linder (2005) suggest that the high cost of understanding a complex tax code induces some taxpayers to pay more taxes than necessary, while other taxpayers may pay less tax if they perceive that tax law complexity makes avoidance more difficult for the IRS to detect. Along similar lines, some studies (Graetz and Wilde, 1985, Milliron, 1985, New York State Bar Association, 1972) suggest that tax law complexity may decrease compliance by creating opportunities for noncompliance. A taxpayer may perceive that tax law complexity makes interpretation of tax laws difficult. In the event of a challenge by the IRS, tax law complexity may provide a defense for the taxpayer that would not exist if tax laws were concise and explicit. The proliferation of tax shelters may be an example of tax law complexity creating opportunities for noncompliance. For example, in the Frontline documentary "Tax Me If You Can", Hendrick Smith (2003) reports on various tax shelters made possible by tax law complexity.

Regarding perceptions of equity, theoretical studies (New York Bar Association, 1972) suggest that tax law complexity should enhance compliance. The argument is that in a complex economy, fairness and equity require tax law complexity, and that resultant perceptions of equity should encourage compliance. However, other studies related to equity (Carnes and Cuccia, 1996; Cuccia and Carnes, 2001, Dean, Keenan and Kenny, 1980; Milliron, 1985) suggest that taxpayers may associate tax law complexity with inequity and unfairness. Taxpayers who perceive that complexity unfairly benefits other taxpayers may feel that noncompliance is justified to correct inequities. Taxpayers who perceive that tax law complexity is not justified may perceive the tax system to be inequitable and may be prone to noncompliance.

Differing perceptions by taxpayers of degree of risk, cost of compliance, magnitude of tax and penalty, inequitable taxation in comparison with other taxpayers, degree of justification for tax law complexity and other factors makes the effects of tax law complexity difficult to determine. The current study attempts to control for some of these factors by creating hypothetical scenarios in which comparisons with other taxpayers and justification is not an issue, and which explicitly state the probability of disallowance of a particular deduction, and the amount of tax and penalty involved. This allows for a focus on differences in perceptions of the morality of taking a particular deduction under conditions of low complexity and high complexity of tax laws. The issue addressed is the message that a society communicates with its tax laws.

\section{Deterrence Factors}

The hypothesis that tax law complexity influences taxpayer behavior through its influence on perceptions of morality is largely based on the general hypothesis that perceptions of morality affect behavior. Consider, then, the general theory of the influence of perceptions of morality on behavior.

The hypothesis that perceptions of morality affects behavior is part of Deterrence Theory (Nagin \& Pogarsky, 2001; Grasmick and Green, 1980, Grasmick and Scott, 1982; Pogarsky, Piquero \& Paternoster, 2004; Silberman, 1976; Wrong, 1961), which posits that when a decision maker contemplates a deviant act, a number of factors may give rise to expectations of potentially undesirable consequences. Such expectations may tend to inhibit or deter a particular behavior. 
Deterrence factors fall into three major categories: (1) formal punishment; (2) informal punishment; and (3) internalized norms or moral commitment. Formal punishment entails officially prescribed penalties imposed on those who are caught and convicted of a forbidden act. Formal punishment may include fines, imprisonment, revocation of licenses and other disciplinary actions. The degree of deterrence is posited to be a function of perceptions of expected punishment. The greater the severity and/or probability of formal punishment the greater the degree of deterrence.

Informal punishment entails social punishment imposed by one's peers, family, friends, co-workers and other associates, when a person's law-breaking is publicly exposed. Perceived consequences of the imposition of informal punishment may include embarrassment, humiliation, social ostracization, and other forms of social stigma. The greater a decision-maker's perceptions of expected social punishment, the greater the degree of deterrence.

Internalized norms or moral commitment entails a decision-maker's belief that certain behaviors are contrary to his or her moral standards. As a result of exposure to the influences of family, religion, schools and other learning experiences, a person may develop personal standards of right and wrong. A person may feel compelled to avoid behavior that is morally wrong. A decision-maker may perceive that if a particular action would violate personal moral standards, feelings of guilt might arise. Even if a person were not caught, and if neither formal punishment nor informal punishment were imposed, feelings of guilt would still arise. The greater the expectation of feelings of guilt, the greater the degree of deterrence.

Reviews of studies of the deterrence of tax noncompliance (Alm, 1991; Andreoni, Erard \& Feinstein, 1998; Cowell, 1990; Graentz \& Wilde, 1985; Hasselding and Bebbington, 1991; Jackson \& Milliron, 1986; Mason \& Calvin, 1978, 1984; Milliron \& Toy, 1988; Roth \& Scholtz, 1989; Witte and Woodbury, 1983; Weigel, Hessing and Elffers 1987) present results that are somewhat mixed. In general, research findings suggest that deterrence factors influence taxpayer behavior in a manner consistent with deterrence theory.

In the current study, formal punishment is defined as a penalty to be imposed in addition to taxes due in the event that a deduction is disallowed by the IRS. In the hypothetical scenarios presented to subjects, magnitude of tax and penalty was held constant, while probability of disallowance was manipulated. Accordingly, expected formal punishment was varied through manipulation of probability of disallowance. Subjects' perceptions of expected social punishment and moral commitment were measured through a questionnaire. In terms of the variables of the current study, deterrence theory hypotheses are as follows:

H1: There is a negative relationship between the probability that the IRS will disallow deductions and inclination to take the deductions.

H2: Greater perception of expected social punishment will be associated with less inclination to take deductions.

H3: Greater perception that taking deductions is immoral will be associated with less inclination to take deductions.

\section{Formation of Moral Values}

To understand how tax law complexity affects perceptions of morality, begin by considering morality in general. Morality entails a person's perceptions of right and wrong behavior. Hazlitt (1964) suggests that social cooperation is the heart of morality. Moral behavior entails conduct that will enhance the well-being of others while also enhancing the well being of the individual. Behavior consistent with the concept of social cooperation includes mutual agreements between people to not kill each other, to not rape, assault, rob or otherwise harm others.

A society's moral values are typically expressed in the form of laws that prohibit certain behavior. However, not all laws reflect morality. In addressing the issue of laws and morality, criminology theory (Hagan, 2008; Inciari, 1993; Siegal, 2007) describe two categories of prohibited actions: mala in se and mala prohibita. A behavior that is mala in se is a behavior that is inherently wrong, and is universally perceived to be immoral. In 
terms of ethical philosophy (Audi, 1997, 2005), mala in se may be related to intuitionism, which suggests that for many behaviors, immorality is self-evident.

An act that is mala prohibita is a crime not because it is inherently wrong, but rather because a law prohibits the act. Along these lines, Healy (2004) describes examples such as shipping products in plastic bags when the law requires paper bags. In some cases laws may be contrary to morality. For example, Hasnas (2006, page 59) states: "But ethics is not coextensive with legality, and responding to legal incentives does not guarantee that an organization is acting ethically, as the Jim Crow legislation that mandated social segregation makes abundantly clear."

Regarding the effects of laws on moral attitudes, it can be inferred that even if there were no laws against murder and assault, most people would consider those acts to be immoral. Conversely, it can be inferred that the existence of laws prohibiting the use of plastic bags will not make most people believe such use is immoral. This would seem to suggest that laws do little to influence morality.

While at the extremes of mala in se and mala prohibita, laws may have little effect on moral attitudes, it seems plausible that there is some middle ground where the morality or immorality of an act is not obvious. For such acts, laws may provide moral guidance. Compliance with tax laws may be an example of that middle ground.

Spicer (1986, p. 13) quotes Justice Oliver Wendell Holmes' statement that "taxes are the price of civilization". If civilization is characterized by social cooperation, and if people benefit from living in a civilized society, it might be inferred that people have a moral obligation to support civilization. To the extent that civilization exists because government provides national defense, police protection, highways, social programs, etc., members of a society perceive a moral obligation to pay taxes.

\section{Tax Law Complexity and Moral Values}

Although people may recognize a moral obligation to pay taxes, there is likely to be a question of what amount of taxes fulfills that moral obligation. It seems plausible that taxpayers perceive their moral obligation to be the amount required by tax law. However, if determining the true amount of tax due is a difficult task, a taxpayer may perceive there to be moral ambiguity.

To understand how tax law complexity may affect taxpayer's attitudes, consider the implication of the general idea that it is largely through laws that a society communicates what it considers to be unacceptable behavior, and that a person's attitudes and expectations may be influenced by laws and punishment for law-breaking. In addressing the issue of punishment as moral education, Wilson \& Herrnstein (1985) suggest that a society teaches disapproval through punishment, stating (on p. 495) that "If punishment tells the members of a community what it considers wrong, the absence of punishment must tell them what it does not consider wrong". This seems to suggest that if a person perceives that society forbids and punishes an action, that person may perceive that action to be immoral. However, if a law is complex and ambiguous, a person may have difficulty determining the moral message that is being communicated.

It might be inferred that the degree to which a behavior is perceived to be morally wrong might be a function of the complexity of laws. If there is a strong consensus that a behavior is unacceptable, that unacceptability will be conveyed through laws that are precise and explicit. However, if a law is imprecise, complex and difficult to interpret, a person may perceive that society feels ambivalent towards the behavior and that the behavior is more acceptable. Accordingly, moral commitment to a complex, imprecise law may be less than the moral commitment to a precise, explicit law.

In the case of taxpayer behavior, it seems plausible that if tax laws regarding a particular deduction were precise and explicit in prohibiting the deduction, a taxpayer would be inclined to perceive taking the deduction to be socially unacceptable tax evasion. Alternately, if tax laws regarding a deduction were complex and imprecise, a taxpayer would be more likely to perceive taking the deduction to be socially acceptable tax avoidance. This would be consistent with the survey findings of Westat (1980, as quoted in Jackson and Milliron, 1986, p. 137) that "If a 
position could be justified by some interpretation of the rules, even though likely to be disallowed by the IRS, the majority of taxpayers felt an aggressive position to be morally defensible."

If tax law complexity gives rise to perceptions that taking questionable deductions is morally justifiable, the following can be hypothesized:

H4: There is a negative relationship between tax law complexity and taxpayers' perceptions that taking deductions is immoral.

Tax law complexity may also be related to expectation of social punishment. If a person's development of moral attitudes arises from perceptions of the expectations of others, and if a person chooses behavior in part to meet those expectations and to please others, it can be inferred that the choice of immoral behavior could result in social punishment. If tax law complexity were to convey that society considers taking questionable deduction to be morally justified, a person may perceive that taking the deduction will not result in social punishment. This can be hypothesized as follows:

H5: There is a negative relationship between tax law complexity and taxpayers' perceptions of expected social punishment that would arise in the event that deductions were disallowed.

If tax law complexity influences taxpayers' perceptions of the social acceptability and morality of taking deductions, and if a person is reluctant to commit an immoral act, then tax law complexity may affect taxpayer behavior through its effects on perceptions of social acceptability and morality. That is, if greater tax law complexity is associated with greater perceptions that taking a deduction is socially acceptable and morally proper, and if a greater perception of social acceptability and moral appropriateness is associated with greater inclination to take a deduction, the following can be hypothesized:

H6: There is a positive relationship between tax law complexity and taxpayer inclination to take deductions that might be disallowed.

The hypothesized relationships are depicted in Figure 1. The arrows between tax law complexity and both expected social punishment and perceptions of morality suggest that tax law complexity influences both expected social punishment and perceptions of morality. The three arrows between probability of penalty, expected social punishment, perception of morality and inclination to take deductions suggest that each of these three deterrence factors influences the inclination to take deductions. If the levels of expected social punishment and perceptions of morality are influenced by tax law complexity, it can be inferred that tax law complexity may affect inclination to take deductions.

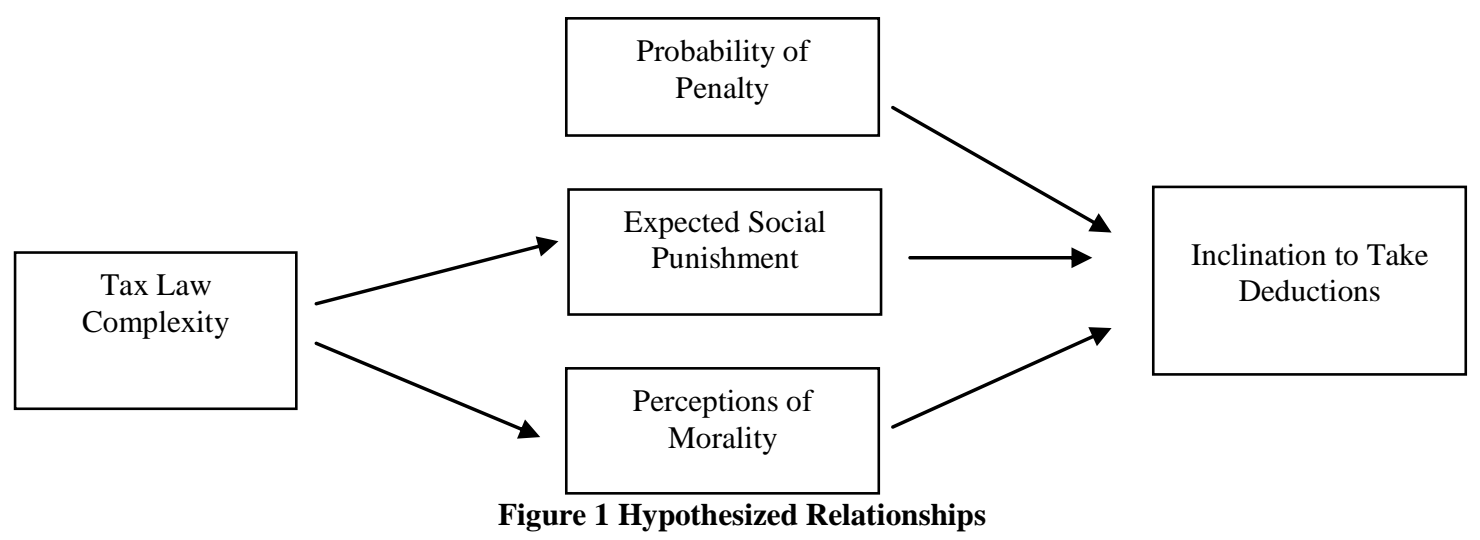




\section{RESEARCH DESIGN}

\section{The Study in General}

The study entailed an experimental survey in which subjects evaluated tax-related hypothetical scenarios, along the lines of studies by Anderson, Harris and Miller (1983); Chang (1984); Kaplan and Reckers (1985); Kaplan, Reckers and Reynolds (1986); Jackson and Spicer (1986); Chang, Nichols and Schultz (1987); Violette (1987); Kaplan, Reckers and Roark (1988); Schadewald (1988, 1989); and Schepanski and Kelsey (1990). Each scenario presented a situation in which the opportunity exists to reduce income taxes by taking certain deductions that might be disallowed. Subjects were told that in the event of disallowance, a penalty would be imposed in addition to unpaid tax.

For each scenario, subjects were asked to imagine that in the preparation of their personal tax returns, they faced the same set of circumstances, and to state the degree to which they would be inclined to take the deduction.

In addition to analyzing a hypothetical scenario, each subject was asked to complete a post-experimental questionnaire addressing demographic data, attitudes, and other information. Items included questions regarding perceptions of expected social consequences and the morality of taking deductions. Sample experimental instruments are presented in the appendix.

\section{Subjects}

Subjects were night students taking graduate business courses at Duquesne University, Robert Morris University and the University of Pittsburgh, plus night undergraduate students at Pennsylvania State University, McKeesport Campus. Many of the subjects had day jobs and had filed tax returns for a number of years. Subjects completed 234 usable surveys.

A summary of subjects' demographics is presented in Figure 2.

\begin{tabular}{|c|c|c|c|c|c|c|}
\hline & Range & Median & & & & \\
\hline Age & $19-58$ & 28 & & & & \\
\hline Years Filed & $0-37$ & 10 & & & & \\
\hline \multirow[t]{2}{*}{ Form Used } & 1040 & $1040 \mathrm{~A}$ & 1040EZ & $\begin{array}{l}\text { Not Required } \\
\text { to File }\end{array}$ & No Response & \\
\hline & $\begin{array}{c}48 \% \\
(114 / 234)\end{array}$ & $\begin{array}{c}27 \% \\
(63 / 234)\end{array}$ & $\begin{array}{c}19 \% \\
(45 / 234)\end{array}$ & $\begin{array}{c}3 \% \\
(7 / 234)\end{array}$ & $\begin{array}{c}2 \% \\
(5 / 234)\end{array}$ & \\
\hline Filing Status & Single & $\begin{array}{c}\text { Married Filing } \\
\text { Jointly }\end{array}$ & $\begin{array}{l}\text { Married Filing } \\
\text { Separately }\end{array}$ & $\begin{array}{l}\text { Head of } \\
\text { Household }\end{array}$ & No Response & \\
\hline & $\begin{array}{c}55 \% \\
(128 / 234)\end{array}$ & $\begin{array}{c}42 \% \\
(98 / 234)\end{array}$ & $\begin{array}{c}0.4 \% \\
(1 / 234)\end{array}$ & $\begin{array}{c}1 \% \\
(3 / 234)\end{array}$ & $\begin{array}{c}2 \% \\
(4 / 234)\end{array}$ & \\
\hline $\begin{array}{l}\text { Household } \\
\text { Income }\end{array}$ & $\begin{array}{c}\text { Less than } \\
\mathbf{\$ 2 0 , 0 0 0} \\
11 \% \\
(23 / 234)\end{array}$ & $\begin{array}{c}\text { \$20,001- } \\
\mathbf{4 0 , 0 0 0} \\
29 \% \\
(67 / 234)\end{array}$ & $\begin{array}{c}\mathbf{\$ 4 0 , 0 0 1 -} \\
\mathbf{7 0 , 0 0 0} \\
36 \% \\
(85 / 234)\end{array}$ & $\begin{array}{c}\$ 70,001- \\
\mathbf{1 0 0 , 0 0 0} \\
14 \% \\
(33 / 234)\end{array}$ & $\begin{array}{c}\text { More than } \\
\mathbf{\$ 1 0 0 , 0 0 0} \\
6 \% \\
(15 / 234)\end{array}$ & $\begin{array}{c}\text { No Response } \\
3 \% \\
(8 / 234)\end{array}$ \\
\hline
\end{tabular}

Figure 2 Subjects' Demographics

\section{Levels of Independent Variables}

To control for some of the problems that arise in the study of tax law complexity, the amount of tax, the amount of penalty and the probability of disallowance were stated in the scenarios. If problems with the determination of the effects of tax law complexity arise from differences in taxpayers' perceptions of the amount of tax involved and the probability of disallowance, the explicit statement of those figures should allow for the focus on the moral message conveyed by tax law complexity. 
In each scenario, the amount of the potential deduction, and the tax rate, were held constant at $\$ 2,000$ and $30 \%$, respectively. Thus, in each scenario, potential tax savings was $\$ 600$.

Probability of disallowance had three levels: $1 \%, 30 \%$ and $60 \%$. A range of probabilities allows the testing of relationships between probability of disallowance and inclination to take deductions. The lowest probability, $1 \%$, which results in very low expected penalty, may provide insight into the deterrent effect of perceptions of expected social consequences and morality. If probability of disallowance were $1 \%$, it might be inferred that any inclination to not take deductions would be due to other factors.

Penalty rate was held constant in all scenarios at $75 \%$ of additional tax imposed. Table 1 presents a calculation of expected outcomes at different levels of probability.

Table 1 Calculation of Expected Outcomes

\begin{tabular}{|cccc|}
\hline $\begin{array}{c}\text { Probability of } \\
\text { Disallowance }\end{array}$ & $\begin{array}{c}\text { Penalty Rate } \\
\text { (as \% of Tax) }\end{array}$ & $\begin{array}{c}\text { Expected Penalty } \\
\text { (2) \% of Tax) } \\
(\mathbf{1}) \mathbf{X}(\mathbf{2})\end{array}$ & $\begin{array}{c}\text { Expected Outcome* } \\
\text { (as \%of Tax) }\end{array}$ \\
\hline $1 \%$ & $75 \%$ & $0.75 \%$ & $98.25 \%$ \\
$30 \%$ & $75 \%$ & $22.50 \%$ & $47.50 \%$ \\
$60 \%$ & $75 \%$ & $45.00 \%$ & $(5.00 \%)$ \\
\hline
\end{tabular}

* Expected Outcome is the expected net benefits of taking the deduction, calculated as potential tax savings reduced by expected additional tax and penalty. Expressed as a percentage of potential tax savings, expected outcome is calculated as [100\% \{Probability of disallowance $(100 \%+$ Penalty Rate $)\}$.

Tax law complexity had two levels: low and high. In the low complexity scenarios, tax laws were described as precise and explicit. The scenario stated that certain deductions are definitely illegal, and that to take the deductions would be tax evasion. Probability of disallowance was described as a function of the audit rate and/or the degree of scrutiny.

In the high complexity scenarios, tax laws were described as complex and ambiguous. The scenarios stated that tax laws regarding the deductions in question are very difficult to understand, and that deductibility is subject to interpretation. Probability of disallowance was expressed in terms of the likelihood that a decision would be made against the taxpayer's position.

\section{Hypothetical Scenarios}

Each hypothetical scenario presented a combination of independent variables described in the preceding. Since there are three levels of probability and two levels of tax law complexity, there were six combinations of independent variables. Each subject evaluated one scenario.

The dependent variable measured in each scenario was inclination to take deductions, measured on a ninepoint scale. Along the lines of instruments administered by Chang (1984); Schadewald (1988); and Schepanski and Kelsey (1990), subjects were asked to state the degree to which they would be inclined to take deductions. Response choices ranged from "definitely would not take the deductions" to "definitely would take the deductions".

A sample experimental instrument is presented in the Appendix.

\section{RESULTS}

Hypotheses were tested by running Analysis of Variance (ANOVA), Regression and related analyses. Data was entered as follows: Degree of inclination was coded on a 9-point scale ranging from 1 for "Definitely would not take the deduction" to 9 for "Definitely would take the deduction". Complexity was coded 1 for "low complexity" and 2 for "high complexity". Probability of disallowance was coded as 1, 30 or 60, corresponding to $1 \%, 30 \%$ and $60 \%$. Morality was coded on a 7-point scale ranging from 1 for "perfectly ethical" to 7 for "extremely unethical". Social consequences was coded on a 7-point scale ranging from 1 for "no adverse social consequences" to 7 for "severe adverse social consequences". 
Consider first the relationship between Inclination to take deductions and the manipulated variables of Probability of disallowance and Complexity of tax laws. Table 2 presents the mean and standard deviation of inclination for each level of Probability and Complexity. Table 3 presents the ANOVA results for Inclination by Probability and Complexity.

Table 2 Breakdown Results Inclination by Probability and Complexity

\begin{tabular}{lccc|}
\hline Probability & $1 \%$ & $30 \%$ & $60 \%$ \\
Mean & 6.0000 & 5.1164 & 4.0897 \\
Std. Dev. & 2.9586 & 2.8007 & 2.4558 \\
Sample Size & $\mathrm{n}=78$ & $\mathrm{n}=78$ & $\mathrm{n}=78$ \\
& & & \\
Complexity & Low & High & \\
Mean & 4.4530 & 5.6838 & \\
Std. Dev. & 2.8512 & 2.7122 & \\
Sample Size & $\mathrm{n}=117$ & $\mathrm{n}=117$ & \\
\hline
\end{tabular}

Table 3 ANOVA Results Inclination by Probability and Complexity

\begin{tabular}{|cccccc|}
\hline Factor & Sum of Squares & DF & Mean Square & F-Stat & Sig of F \\
\hline Probability & 142.573 & 2 & 71.286 & 9.906 & .0000 \\
Complexity & 88.615 & 1 & 88.615 & 12.314 & .001 \\
\hline
\end{tabular}

The tables show that the effects of Probability is highly significant $(F=9.906$, Sig of $F=.0000)$ in the predicted direction. Higher levels of probability of disallowance are associated with lower inclination to take questionable deductions. This is consistent with Hypothesis \# 1. The effects of Complexity is also highly significant $(\mathrm{F}=12.314$, Sig of $\mathrm{F}=.001)$ in the predicted direction. Greater complexity of tax laws is associated with greater inclination to take questionable deductions. This is consistent with Hypothesis \# 6.

To test the effects of measured variables, regressions were run. Table 4 presents regression results for Inclination and Expected Social Consequences of taking questionable deductions. The negative relationship is highly significant $(T=-6.784$, Sig of $T=.0000)$ in the predicted direction, consistent with Hypothesis \# 2. Greater perception that taking deductions would result in adverse social consequences is associated with less inclination to take deductions.

Table 4 Regression Results: Inclination vs. Social Consequences

\begin{tabular}{|llcccc|}
\hline \multicolumn{1}{|c}{ Variable } & Constant & B & SE of B & T-Stat & Sig of T \\
\hline $\begin{array}{l}\text { Social } \\
\text { Consequences }\end{array}$ & 7.038950 & -.684146 & .100845 & -6.784 & .0000 \\
\hline
\end{tabular}

R Value: .40687; R Squared: .16554

Table 5 presents regression results for Inclination and perceptions of the Morality of taking questionable deductions. The negative relationship is highly significant $(\mathrm{T}=-10.449$, Sig of $\mathrm{T}=.0000)$ in the predicted direction, consistent with Hypothesis \# 3. Greater perception that taking deduction is immoral is associated with less inclination to take deductions.

Table 5 Regression Results: Inclination vs. Perceptions of Morality

\begin{tabular}{|cccccc|}
\hline Variable & Constant & B & SE of B & T-Stat & Sig of T \\
\hline Morality & 8.420151 & -.859995 & .082306 & -10.449 & 0000 \\
\hline
\end{tabular}

R Value: .56568; R Squared: .32000 
As a further test of the effects of expected social consequences and perceptions of morality, Table 6 presents results of a multiple regression. Inclination was the dependent variable. Expected social consequences and perceptions of morality were independent variables. For expected social consequences, the negative relationship was significant $(\mathrm{T}=-2.644415$, Sig of $\mathrm{T}=.0087)$ in the predicted direction, consistent with Hypothesis \# 2. For perceptions of morality, the negative relationship was significant $(T=-7.813511$, Sig of $T=.0000)$, consistent with Hypothesis \# 3.

Table 6 Multiple Regression Results: Inclination vs. Social Consequences and Perceptions of Morality

\begin{tabular}{|lccccc|}
\hline \multicolumn{1}{|c}{ Variable } & Constant & B & SE of B & T-Stat & Sig of T \\
\hline $\begin{array}{l}\text { Social } \\
\text { Consequences }\end{array}$ & 8.724576 & -.275067 & .104018 & -2.644415 & .0087 \\
Morality & & -.73482 & .094045 & -7.813511 & .0000 \\
\hline
\end{tabular}

Multiple R Value: .583076; Multiple R Squared: .339978

The lower levels of significance in the multiple regression is reasonable considering that perceptions of morality is theorized to be influenced by societal expectations and that expected social consequences and perceptions of morality could be expected to be related. That relationship is addressed in Table 7, which reports the regression results of perceptions of morality and expected social consequences. There is a significant positive correlation $(T=8.872292$, Sig of $T=.0000)$.

Table 7 Regression Results: Perceptions of Morality vs. Social Consequences

\begin{tabular}{|lccccc|}
\hline \multicolumn{1}{|c}{ Variable } & Constant & B & SE of B & T-Stat & Sig of T \\
\hline $\begin{array}{l}\text { Social } \\
\text { Consequences }\end{array}$ & 2.293931 & .556707 & .062747 & 8.872292 & .0000 \\
\hline
\end{tabular}

R Value: .50333; R Squared: .253341

Next consider the effects of complexity on expected social consequences and perceptions of morality. Table 8 presents Means and Standard Deviations of expected social consequences for each level of complexity. Table 9 presents ANOVA results for expected Social Consequences by Complexity.

Table 8 Breakdown Results: Social Consequences by Complexity

\begin{tabular}{|lcc|}
\hline \multicolumn{1}{|c|}{ Level of Complexity } & Low & High \\
\hline Mean & 3.1795 & 2.5812 \\
Standard Deviation & 1.6949 & 1.6413 \\
Sample Size & $\mathrm{n}=117$ & $\mathrm{n}=117$ \\
\hline
\end{tabular}

Table 9 Anova Results: Social Consequences by Complexity

\begin{tabular}{|ccccccc|}
\hline Factor & Sum of Square & DF & Mean Square & F-Stat & Sig of F \\
\hline Complexity & 20.940 & 1 & 20.940 & 7.524 & .007 \\
\hline
\end{tabular}

These tables show that the relationship between expected social consequences and complexity is significant $(\mathrm{F}=7.524$, Sig of $\mathrm{F}=.007)$ in the predicted direction. Greater tax law complexity is associated with less expectation of social punishment, consistent with Hypothesis \# 5.

Table 10 presents Means and Standard Deviations of perceptions of Morality for each level of Complexity. Table 11 presents ANOVA results for perceptions of Morality by Complexity.

Table 10 Breakdown Results: Perceptions of Morality by Complexity

\begin{tabular}{|lcc|}
\hline \multicolumn{1}{|c|}{ Level of Complexity } & Low & High \\
\hline Mean & 4.5385 & 3.2564 \\
Standard Deviation & 1.7298 & 1.7915 \\
Sample Size & $\mathrm{n}=117$ & $\mathrm{n}=117$ \\
\hline
\end{tabular}

Table 11 ANOVA Results: Perceptions of Morality by Complexity

\begin{tabular}{|cccccc|}
\hline Factor & Sum of Square & DF & Mean Square & F-Stat & Sig of F \\
\hline Complexity & 96.154 & 1 & 96.154 & 31.009 & .000 \\
\hline
\end{tabular}


These tables show that the relationship between perceptions of Morality and level of Complexity is highly significant $(\mathrm{F}=31.009$, Sig of $\mathrm{F}=.000)$ in the predicted direction. Greater tax law complexity is associated with less perception that taking a deduction is immoral, consistent with Hypothesis \# 4.

\section{DISCUSSION AND CONCLUSIONS}

The results are consistent with the hypotheses. Tax law complexity is significantly related to inclination to take deductions, consistent with Hypothesis \# 6. This seems to suggest that complex and ambiguous tax laws may give rise to greater tendency for taxpayers' to take questionable deductions than if tax laws were precise and explicit.

The results are also consistent with deterrence theory, addressed by Hypotheses \# 1, \# 2, and \# 3 . Significant relationships suggest that deterrence factors of probability of disallowance, expectations of social punishment, and perceptions that taking deductions is immoral are statistically related to taxpayers' inclination to take questionable deductions. It can be inferred that if levels of deterrence factors were to change, inclination to take questionable deductions might change as well.

The remaining hypotheses, which address the question of whether tax law complexity might influence moral and social factors (Hypotheses \# 4 and \# 5), are supported as well. Complexity is significantly related to both perceptions of morality and expectations of social punishment. This seems to be consistent with the suggestion that if tax laws were precise and explicit rather than complex and ambiguous, taxpayers might be more prone to expect the taking of questionable deductions to lead to social punishment, and to perceive the taking of those deductions to be immoral.

With regard to the influence of complexity, it should be noted that while statistically significant results suggest that complexity may affect social expectations and moral attitudes, complexity is by no means the sole determinant of a taxpayer's expectations and attitudes. Many factors influence a person's social expectations and moral attitudes, including family, religion, friends and other social factors, as well as complexity of laws. Accordingly, the elimination of tax law complexity could not be expected to result in the perception that noncompliance is morally reprehensible. However, it seems plausible that reduction in tax law complexity might contribute to an increase in the perception that noncompliance is immoral and socially unacceptable, and, in turn, would contribute to a reduction in noncompliance.

It should also be noted that most determinants of social expectations and moral attitudes are beyond the control of tax policy makers. Also, in a large, complex economy, tax law complexity may be necessary. To provide for the deductibility of a large array of legitimate expenses, to encourage investment, to encourage home ownership and other policy objectives, tax law complexity may be justified. A degree of noncompliance may be a reasonable trade-off for the achievement of policy objectives. However, if the reduction of tax law complexity could have a marginal effect on compliance, tax policy makers may want to at least consider the reduction of unnecessary tax law complexity.

\section{AUTHOR INFORMATION}

David Nugent has a Ph.D. in business administration from the Katz Graduate School of Business at the University of Pittsburgh. He has an MBA and a BS in business administration from Duquesne University, and is a CPA in Pennsylvania. He has been a faculty member at a number of universities, most recently as a Visiting Assistant Professor of Accounting and Taxation at Robert Morris University. E-mail: davidanugent@ hotmail.com

\section{REFERENCES}

1. Alm, J. (1988). Uncertain Tax Policies, Individual Behavior, and Welfare. American Economic Review, 78, 237-245.

2. Alm, J. (1991). A Prospective on the Experimental Analysis of Taxpayer Reporting. The Accounting Review, 66, 577-593. 
3. Anderson, A. B., Harris A.R., \& Miller J. (1983). Models of Deterrence Theory. Social Science Research, $12,236-262$.

4. Andreoni, J., Erard, B., \& Feinstein, J. (1998). Tax Compliance. Journal of Economic Literature, 36(2) 818-860.

5. $\quad$ Audi, R. (1997). Moral Knowledge and Ethical Character. Oxford: Oxford University Press.

6. Audi, R. (2005). The Good in the Right: A Theory of Intuition and Intrinsic Value. Princeton: Princeton University Press.

7. Boortz, N., and Linder, J. (2005). The Fair Tax Book. New York: Harper Collins Publishers.

8. Carnes, G. A., and Cuccia, A. D. (1996). An Analysis of the Effect of Tax Complexity and its Perceived Justification on Equity Judgments. Journal of the American Taxation Association, 18, 40-56.

9. Cuccia, A. D., and Carnes, G. A. (2001). A Closer Look at the Relation Between Tax Complexity and Tax Equity Perceptions.

10. Chang, O. H. (1984). Tax Avoidance Behavior: A Prospect Theory Perspective. (Doctoral Dissertation, University of Illinois at Urbana-Champaign, 1984).

11. Chang, O.H., Nichols D.R., \& Schultz, J.J. Jr., (1987). Taxpayer Attitudes Toward Tax Audit Risk. Journal of Economic Psychology, 8, 299-309.

12. Cowell, F. A. (1990). Cheating the Government. Cambridge, MA: The MIT Press.

13. Dean, P., Keenan, T., and Kenny, F. (1980). Taxpayers' Attitudes to Income Tax Evasion: An Empirical Study. British Tax Review, 1, 28-44.

14. Graentz, M. J., and Wilde L.L. (1985). The Economics of Tax Compliance: Fact and Fantasy. National Tax Journal, 38, 355-363.

15. Grasmick, H. G. \& Green, D.E. (1980). Legal Punishment, Social Disapproval and Internalization as Inhibitors of Illegal Behavior. Journal of Criminal Law and Criminology, 71, 325-335.

16. Grasmick, H.G., \& McLaughlin, S.D. (1978). Deterrence and Social Control (Comment on Silberman, American Sociological Review, June, 1976). American Sociological Review, 3, 272-277.

17. Grasmick, H.G., \& Scott, W.J. (1982). Tax Evasion and Mechanisms of Social Control: A Comparison With Grand and Petty Theft. Journal of Economic Psychology, 2, 213-230.

18. Hagan, F.E. (2008). Introduction to Criminology. Los Angeles, CA: Sage Publications, Inc.

19. Hasnas, J. (2006). Trapped: When Acting Ethically is Against the Law. Cato Institute.

20. Hasselding, D. J., \& Bebbington, K.J., (1991). Blending Economic Deterrence and Fiscal Psychology Models in the Design of Responses to Tax Evasion: The New Zealand Experience. Journal of Economic Psychology, 12, 299-324.

21. Hazlitt, H. (1964). The Foundations of Morality. New York: D. Van Nostrand Company, Inc.

22. Healy, G. (2004). Go Directly to Jail: The Criminalization of Almost Everything. Cato Institute.

23. Hite, P. A., and McGill, A. (1992). An Economic Examination of Taxpayer Preference for Aggressive Tax Advice. National Tax Journal, 45, 389-404.

24. Inciardi, J. A. (1993). Criminal Justice. New York: Harcourt Brace \& Company.

25. Jackson, B. R., \& Milliron, V.C. (1986). Tax Compliance Research, Findings, Problems and Prospects. Journal of Accounting Literature, 5, 125-166.

26. Jackson, B.R. \& Spicer, M.W. (1986). An Investigation of Under or Over Withholding of Taxes on Taxpayer Compliance. Arthur Young Tax Research Grant Report, Working Paper No. 85-57.

27. Kaplan, S. E., \& Reckers, P.M.J. (1985). A Study of Tax Evasion Judgments. National Tax Journal, 38, 97102.

28. Kaplan, S.E., Reckers, P.M.J \& K. D. Reynolds, (1986). An Application of Attribution and Equity Theories.

29. Kaplan, S.E., Reynolds, K.D. \& Roark, S.J. (1988). An Attribution Theory Analysis of Tax Evasion Related Judgments. Accounting, Organizations and Society, 13, 371-379.

30. Mason, R., \& Calvin, L.D. (1978). A Study of Admitted Income Tax Evasion. Law and Society Review, 13, 73-89.

31. Mason, R. \& Calvin L.D. (1984). Public Confidence in the Tax System and Admitted Income Tax Evasion. National Tax Journal, 37, 489-496.

32. Milliron, V. C. (1985). An Analysis of the Relationship Between Tax Equity and Tax Complexity. Journal of the American Taxation Association, 6, 19-33. 
33. Milliron, V.C., \& Toy, D.R. (1988). Tax Compliance: An Investigation of Key Features. Journal of the American Taxation Association, 9, 84-104.

34. Nagin, D.S., and Pogarsky, G. (2001). Integrating Celerity, Impulsivity, and Extralegal Sanction Threats Into a Model of General Deterrence: Theory and Evidence. Criminology, 39(4), 865-891.

35. New York State Bar Association. (1972). A Report on Complexity and the Income Tax. Tax Law Review, 329-376.

36. Pogarsky, G., Piquero, A.R. \& Paternoster, R. (2004). Modeling Change in Perceptions about Sanction Threats: The Neglected Linkage in Deterrence Theory. Journal of Quantitative Criminology, 20(4), 343369.

37. Roth, J. \& Scholtz, J.T. (Eds). (1989). Taxpayer Compliance Volume 2: Social Science Perspectives. Philadelphia, PA: University of Pennsylvania Press.

38. Schadewald, M. S. (1988). Reference Outcome Effects in Taxpayer Decision Making. (Doctoral Dissertation, University of Minnesota, 1988).

39. Schadewald, M.S. (1989). Reference Point Effects in Taxpayer Decision Making. Journal of the American Taxation Association, 10, 68-84.

40. Schepanski, A., \& Kelsey, D. (1990). Testing For Framing Effects in Taxpayer Compliance Decisions.

41. Siegel, L.J. (2007). Criminology. Belmont, CA: Thomson Wadsworth.

42. Silberman, M. (1976). Towards a Theory of Criminal Deterrence. American Sociological Review, 41, 442461.

43. Smith, H. (2003). Frontline Report, Tax Me if You Can, retrieved from http://www.pbs.org/wghb/pages/frontline/shows/tax/etc/synopsis.html

44. Spicer, M. W. (1986). Civilization at a Discount: The Problem of Tax Evasion. National Tax Journal, 39 , 13-20.

45. Violette, G. R. (1987). The Deterrence Effects of Sanction Communications on Taxpayer Level of Income Tax Compliance. (Doctoral Dissertation, Arizona State University, 1987).

46. Weigel, R. H., Hessing, D.J. \& Elffers, H. (1987). Tax Evasion Research: A Critical Appraisal and Theoretical Model. Journal of Economic Psychology, 8, 215-235.

47. Westat, Inc. (1980), Individual Income Tax Compliance Factors Study, Qualitative Research. Prepared for the Internal Revenue Service, February.

48. Wilson, J. Q., \& Herrnstein, R.J. (1985). Crime and Human Nature. New York: Simon and Schuster.

49. Witte, A. D., \& Woodbury, D.F. (1983). What We Know About the Factors Affecting Compliance With the Tax Laws, In Sawicki, P. (Ed.), Income Tax Compliance: A Report to the ABA Section of Taxation Invitational Conference on Tax Compliance. Washington, D.C.: American Bar Association.

50. Wrong, D. H., (1961). The Oversocialized Conception of Man in Modern Sociology. American Sociological Review, 26, 183-193. 


\section{APPENDIX: SAMPLE INSTRUMENT}

(It should be noted that in the surveys completed by subjects, the terms "low complexity scenario" and "high complexity scenario" were not stated. Those phrases are included to provide a better understanding by the reader of this paper)

\section{INSTRUCTIONS}

Thank you for agreeing to participate in this research project. Your cooperation is greatly appreciated.

This study entails your evaluation of a series of tax-related scenarios. In this study we seek to better understand the decision-making processes of taxpayers.

We want to emphasize that this study is being conducted by academic researchers. This research project is not connected to the IRS or any other taxing authority. The identity of participants will be kept strictly confidential. Individual responses will be anonymous. Do not write your name on this document.

\section{PART 1}

In this section you are to evaluate a hypothetical scenario entailing the filing of a tax return. Please read the scenario carefully and thoroughly and then state what you would do if you were the taxpayer in the scenario.

You may notice that the conditions described and other information presented may differ from your perceptions of the real world. These differences are intentional and are an important part of the study. One of the goals of this study is to gain a better understanding of decision making in a variety of hypothetical scenarios. Accordingly, we want you to carefully read the scenario, and respond as though you actually faced the circumstances described in each scenario.

Please turn the page and begin.

\section{Low Complexity Scenario (See Note Above)}

Assume that it is April and you are preparing to file your Federal income tax return. Further assume that you are employed in a job requiring travel and meeting with clients. When you file your tax return, you take deductions for employee business expenses, including travel and entertainment.

During the year you incurred a number of unreimbursed expenditures including trips that were part business and part personal vacation, living expenses for family members who accompanied you on temporary out of town assignments, meeting with clients at restaurants and nightclubs, and other similar expenditures.

A tax consultant has told you that some of these expenditures are not deductible. The tax laws with regard to these particular expenditures are precise and explicit. To deduct these items as part of employee business expenses would be tax evasion.

Further assume that due to limitations in the IRS's ability to thoroughly scrutinize all tax returns, there is some likelihood that the IRS would not challenge the deduction.

The expenditures under consideration total $\$ 2,000$, and your tax rate is $30 \%$; Thus, if you were to take the deductions, your tax savings would be $\$ 600$.

In the event of disallowance, tax must be paid. And since, in that event, the additional taxes represent underpayment, additional costs are imposed in the form of interest, penalties, fines, legal costs and other expenses which are to be collectively designated as "penalty". 
High Complexity Scenario (See Note On Preceding Page)

Assume that it is April and you are preparing to file your Federal income tax return. Further assume that you are employed in a job requiring travel and meeting with clients. When you file your tax return, you take deductions for employee business expenses, including travel and entertainment.

During the year you incurred a number of unreimbursed expenditures, including trips that were part business and part personal vacation, living expenses for family members who accompanied you on temporary out of town assignments, meeting with clients at restaurants and nightclubs, and other similar expenditures.

A tax consultant has told you that determination of the deductibility of some of these expenditures is difficult. The tax laws regarding employee business expenses are very complex, ambiguous and difficult to understand. The deductibility of these items is subject to interpretation. Accordingly, there is some likelihood that the IRS may challenge these deductions. However, because of the complexity and ambiguity of the tax laws, the resolution of the matter could be in your favor.

The expenditures under consideration total $\$ 2,000$, and your tax rate is $30 \%$; Thus, if you were to take the deductions, your tax savings would be $\$ 600$.

In the event of disallowance, tax must be paid. And since, in that event, the additional taxes represent underpayment, additional costs are imposed in the form of interest, penalty, fines, legal costs, and other expenses which are to be collectively designated as "penalty".

Assume that the penalty rate is $75 \%$ of additional taxes. Thus, in the event of disallowance, $\$ 600$ of tax will be imposed, plus a penalty of $\$ 450$.

Assume that a tax consultant has told you that if you do choose to take the deductions, there is a $1 \%$ probability that the IRS will disallow it.

If you faced this scenario, how inclined would you be to take the deductions? (Indicate the one statement that is most appropriate.)

Definitely would take the deductions.

Strongly inclined to take the deductions.

Moderately inclined to take the deductions.

Slightly inclined to take the deductions.

Indifferent between taking and not taking the deductions.

Slightly inclined to not take the deductions.

Moderately inclined to not take the deductions.

Strongly inclined to not take the deductions.

Definitely would not take the deductions.

\section{PART 2} questionnaire:

As the final stage of this study, we would greatly appreciate your completion of the following

(1) (A) In evaluating the hypothetical scenario presented in Part 1, to what extent were you able to realistically imagine what your reaction would have been in the same situation?

I could imagine what my reaction would be without question

To a very high degree

To a moderate degree

To a slight degree

Not at all 
(1) (B) If the additional tax and the penalty imposed, as described in the scenario, were imposed on you personally, how substantial a hardship (if at all) would it be?:

No financial hardship at all.

A slight financial hardship.

A moderate financial hardship.

A severe financial hardship.

- A catastrophic financial hardship.

(2) (A) Which tax form do you typically use when filing you tax return?

\begin{tabular}{lll} 
Form 1040 & (long form) \\
\hline & Form 1040A & (short form) \\
& Form 1040 EZ & \\
& Not required to file, because
\end{tabular}

(2) (B) Approximately how many years have you filed a tax return?

(3) (A) In filing your own personal tax return, if you were to face the circumstances described in the scenario, to what extent would you consider taking the deductions to be immoral or unethical?:

Perfectly

Ethical

12
3
4
Extremely Unethical

5

6

7

expect

to

(3) (B) If you were to take the deductions described in the scenario, to what extent would you experiences feelings of guilt?:

No Feelings

of Guilt

12

23

34

4

5

Great Feelings

of Guilt

6

7

(3) (C) Assuming that you were to take the deductions described in the scenario, and that your personal tax return was subsequently audited, an underpayment determined, and penalties imposed: to what extent (if at all) would you expect embarrassment, social castigation or other forms of adverse social consequences?

No Adverse

Social Consequences

1

2

3

4

5

6

Severe Adverse Social Consequences

(3) (D) To what extent do you consider yourself to be familiar with IRS regulations and enforcement activities?

Not At All

Very

Familiar

Familiar

1

2

3

4

5

6

7 
(3) (E) To what extent do you consider the amount of taxes you pay to be fair and equitable in relation to the total benefits you receive from the government?

My taxes paid are much less than the benefits I receive.

My taxes paid are somewhat less than the benefits I receive.

My taxes paid and benefits received are just about in balance.

_ My taxes paid are somewhat more than the benefits I receive.

__ My taxes paid are much greater than the benefits I receive.

(4) (A) What is your age?

(4) (B) Gender? _ _ Male _ _ Female

(4) (C) What is your filing status? __ Single __ _ _ Married, Joint Return _ Married, Separate Return __ _ Head of Household

(4) (D) What is the highest level of education you have completed?

Less than 12 years
$\_$High School
Some College
College (Associate's Degree)

College (Bachelor's Degree)

Master's Degree

Doctorate

(4) (E) What is your occupation?

(4) (F) What is your annual household income?

Under $\$ 20,000$

$\$ 20,001-\$ 40,000$

$\$ 40,001-\$ 70,000$

$\$ 70,001-\$ 100,000$

More than $\$ 100,000$ 